\title{
Changes in the lifestyle and feeding habits that could improve the planet and human health: the reproductive case
}

Sir,

There is a link between food systems, environment, and human health. According to the Food and Agriculture Organization of the United Nations-FAO, food production from animal and plant origin, using unsustainable agricultural practices with the excessive use of fertilizers, pesticides, fungicides, and herbicides have adverse effects on the environment and could contaminate water sources and even the soil. ${ }^{1}$ Also, the production of food from animal origin is one of those responsible for the emission of greenhouse gases, fresh water expenditure, and soil loss. Therefore, with the current food consumption and unsustainable human practices, the future of humanity will be uncertain.

Two international commissions have focused on studying the impact of food production systems for proposing resilient alternatives..$^{2-5}$ In both the central axis is sustainability and the actions to sustain the "planetary health", it will be achieved with practices such as the first instance reducing food waste, which has been declared a global problem. The intergovernmental panel on climate change -IPCC- reports that one-third of the food produced is lost or wasted. ${ }^{6}$

In the particular case of Colombia according to the Departamento Nacional de Planeación around ten million tons of food are lost or wasted per year, which represents $34 \%$ of the total food that could be consumed it has been calculated that more than 8 million people could be fed per year. ${ }^{7}$ The EAT-Lancet commission has declared that: with the reduction of losses or waste, changes in food production practices, the modification of diet, can help alleviate hunger the many populations, which by 2050 is projected of 10 billion people, additionally avoid catastrophic damage to the planet and improve health. ${ }^{8}$

In the second-order, a change in the eating habits of the population has been proposed, the called planetary health diet (diet-planet-health) that emerged by the EAT-Lancet commission. ${ }^{8}$

They formulate for a diet of 2500 calories a consumption of red meat of $14 \mathrm{~g} / \mathrm{day}$, it means $100 \mathrm{~g} / \mathrm{week}$, the consumption of chicken or other birds or fish $57 \mathrm{~g} /$ day, it means almost $400 \mathrm{~g}$ per week, eggs $13 \mathrm{~g} /$ day, that is between 2 and 3 eggs a week, and the highest proposal of protein from animal origin is the consumption of 250 $\mathrm{g} /$ day of dairy products. This diet proposes a reduction in meat consumption of about $50 \%$ with double the consumption of plant-based food, fruits and vegetables $500 \mathrm{~g} /$ day, whole grains and tubers $282 \mathrm{~g} /$ day; legumes, nuts, and seeds $125 \mathrm{~g} /$ day. In short, a paradigm shifts, concerning to the diets that are proposed today that include lees amounts of protein of animal origin.

In their report, these commissions go beyond proposing a type of diet. They try to suggest ways for production and consumption to minimize the impact on the environment and human health. They want to reach a broad and open audience that is concerned about the environment care and even human health; they also discuss reducing the consumption of animal products. In the last IPCC recently released a report they include plant-based diets as a significant opportunity for mitigating and adapting to climate change. ${ }^{6,9}$

In this sense, the vegetarian diet becomes a kind of diet that contributes to sustainability. ${ }^{10,11}$ Although vegetarianism includes a diverse and heterogeneous range of foods, it is common to all diets the reduction of the consumption of products of animal origin.

In other cases, the consumption of vegetable origin is increased in order to meet the nutrient needs of macro and micronutrients of the persons. However, beyond food, the term vegetarianism and veganism includes an identity and lifestyle, which may be in line with the sustainable, for example some vegetarians eliminate the use of leather or materials that come from animals in their clothing, use brands of beauty products in which no animal tests have been performed, choose organic plant-based foods instead of conventionally produced food, among other practices that imply a more conscious approach to the impact that as humans we can make to the planet. ${ }^{12}$

Many people still worry about the possibility that a vegetarian diet does not provide the nutrients and calories necessary to maintain good health, but there is growing evidence that a plant-based diet such as the vegetarian diet and even the vegan, adequately planned, can be a complete diet, it provides a sufficient amount of calories to maintain a healthy weight and all the nutritional compounds required to maintain a functional nutritional status. ${ }^{13,14}$

In addition, vegetarian diets have long been recognized for conferring protection against diseases such as 
cardiovascular dysfunctions, diabetes mellitus type 2, cancer, and cardiometabolic risk factors such as hypertension and obesity. ${ }^{15-19}$ This kind of diet have a food profile characterized by a higher intake of whole grains, fruits, soy and derivatives, legumes, vegetables, especially dark green leaves, nuts, seeds and in some cases higher intake of milk and dairy products low fat, therefore it could contribute of high content of fiber, magnesium, potassium, vitamin $\mathrm{A}$, vitamin $\mathrm{C}$, vitamin $\mathrm{E}$, thiamine, riboflavin, folates, carotenoids, flavonoids and other phytochemicals with great antioxidant potential, at the same time that is low in saturated fat, cholesterol, sodium, reasons that could explain the health benefits. ${ }^{20,21}$

The environmental changes to which we are exposing as the pollutants, some of these, product of agricultural practices that we have, the new lifestyles, the liquor, the cigarette are having an unfavourable impact on weight, metabolism and human health and in the male case, could be related to changes in seminal quality that have been documented in recent years. ${ }^{22-25}$

Decrease and alterations in seminal parameters has been related to decreased in male fertilizing capacity and there could be a close relationship between some unhealthy life habits, including a rich in animal fat, sugar, salt, highcalorie content, and food with low nutritional value with the decrease in seminal quality, while diets that include fruits, vegetables, fish and low-fat products as a source of protein are associated with better seminal quality. ${ }^{26-30}$

Therefore, it is expected that the change for a healthier diet, will help the health of the planet, and as a consequence will have a positive impact on many aspects of human well-being, specifically, in men, in their sexual and reproductive health, improving the quality of sperm. We insist that implementing changes and interventions in the lifestyle, including the consumption of a vegetarian diet, based on the concept of planetary diet, would support the food change proposed by organizations such as FAO and the IPCC. It is a type of diet that allows maintaining a good nutritional status, preventing the development of obesity and diseases such as chronic noncommunicable, while contributing to improving seminal quality and fertilization rates positively. ${ }^{29}$

The sum of efforts such as those that are proposed, surely in the near future, will prevent us from ending the one that until now and surely for a long time will be the only planet on which we can live and will contribute to the well-being of current generations and generations future.

Authors are convinced that small personal food changes will contribute to a massive change for the planet, in other words... "that is one small step for a man, one giant leap for mankind (Neil Armstrong)".

\section{Alejandra María Gómez Gutiérrez ${ }^{1,2}$, Briana D. Gómez Ramírez ${ }^{3}$, Walter D. Cardona Maya ${ }^{1 *}$}

${ }^{1}$ Reproduction Group, Department of Microbiology and Parasitology, Medical School, University of Antioquia, Antioquia, Colombia

${ }^{2}$ Department of Physiology and Biochemistry, Medical School, University of Antioquia, Antioquia, Colombia ${ }^{3}$ School of Nutrition and Dietetics, University of Antioquia, Antioquia, Colombia

*Correspondence:

Walter D. Cardona Maya, E-mail: wdario.cardona@udea.edu.co.

\section{REFERENCES}

1. Food and Agriculture Organization of the United Nations. The future of food and agriculture-Trends and challenges. Food and Agriculture Organisation Rome. 2017. Available at: http://www.fao.org/3/ai6583e.pdf. Accessed on $9^{\text {th }}$ September 2019.

2. Knuppel A, Papier K, Key TJ, Travis RC. EATLancet score and major health outcomes: the EPICOxford study. Lancet. 2019;394(10194):213-4.

3. Rockstrom J, Stordalen GA, Horton R. Acting in the Anthropocene: the EAT-Lancet Commission. Lancet. 2016;387(10036):2364-5.

4. Willett W, Rockstrom J, Loken B, Springmann M, Lang $\mathrm{T}$, Vermeulen $\mathrm{S}$, et al. Food in the Anthropocene: the EAT-lancet commission on healthy diets from sustainable food systems. Lancet. 2019;393(10170):447-92.

5. Swinburn BA, Kraak VI, Allender S, Atkins VJ, Baker PI, Bogard JR, et al. The global syndemic of obesity, undernutrition, and climate change: The Lancet Commission report. Lancet. 2019;393(10173):791-846.

6. Intergovernmental Panel on Climate Change. Climate Change and Land. 2019. Available at: https://www.ipcc.ch/report/srccl/2019. Accessed on $9^{\text {th }}$ September 2019.

7. Departamento Nacional de Planeación. Pérdida y Desperdicios de Alimentos en Colombia. 2016. Available at: https://mrv.dnp.gov.co/Documentos de Interes/Perdida_y_Desperdicio_de_Alimentos_en_co lombia.pdf. Accessed on $9^{\text {th }}$ September 2019.

8. The EAT-Lancet Commission. EAT-Forum 2019. Available at: https://eatforum.org. Accessed on $9^{\text {th }}$ June 2014.

9. Schiermeier Q. Eat less meat: UN climate-change report calls for change to human diet. Nature. 2019;572(7769):291-2.

10. Ruby MB, Heine SJ, Kamble S, Cheng TK, Waddar M. Compassion and contamination. Cultural differences in vegetarianism. Appetite. 2013;71:340-8. 
11. Rosenfeld DL, Burrow AL. Vegetarian on purpose: Understanding the motivations of plant-based dieters. Appetite. 2017;116:456-63.

12. Cramer H, Kessler CS, Sundberg $T$, Leach MJ, Schumann D, Adams J, et al. Characteristics of Americans choosing vegetarian and vegan diets for health reasons. J Nutr Educ Behav. 2017;49(7):561-7 e1.

13. Farmer B, Larson BT, Fulgoni VL, Rainville AJ, Liepa GU. A vegetarian dietary pattern as a nutrientdense approach to weight management: an analysis of the national health and nutrition examination survey 1999-2004. J Am Diet Assoc. 2011;111(6):819-27.

14. Clarys P, Deliens T, Huybrechts I, Deriemaeker P, Vanaelst B, De Keyzer W, et al. Comparison of nutritional quality of the vegan, vegetarian, semivegetarian, pesco-vegetarian and omnivorous diet. Nutrit. 2014;6(3):1318-32.

15. Lin TJ, Tang SC, Liao PY, Dongoran RA, Yang JH, Liu CH. A comparison of L-carnitine and several cardiovascular-related biomarkers between healthy vegetarians and omnivores. Nutrit. 2019;66:29-37.

16. Tonstad S, Stewart K, Oda K, Batech M, Herring RP, Fraser GE. Vegetarian diets and incidence of diabetes in the Adventist Health Study-2. Nutr Metab Cardiovasc Dis. 2013;23(4):292-9.

17. Cui X, Wang B, Wu Y, Xie L, Xun P, Tang Q, et al. Vegetarians have a lower fasting insulin level and higher insulin sensitivity than matched omnivores: A cross-sectional study. Nutr Metab Cardiovasc Dis. 2019;29(5):467-73.

18. Garbett TM, Garbett DL, Wendorf A. Vegetarian diet: a prescription for high blood pressure? A systematic review of the literature. The $\mathrm{J}$ Nurse Pract. 2016;12(7):452-8.e6.

19. Mihrshahi S, Ding D, Gale J, Allman-Farinelli M, Banks E, Bauman AE. Vegetarian diet and all-cause mortality: Evidence from a large population-based Australian cohort - the 45 and Up Study. Prev Med. 2017;97:1-7.

20. Orlich MJ, Jaceldo-Siegl K, Sabate J, Fan J, Singh PN, Fraser GE. Patterns of food consumption among vegetarians and non-vegetarians. $\mathrm{Br} \quad \mathrm{J}$ Nutr. 2014;112(10):1644-53.

21. Rizzo NS, Jaceldo-Siegl K, Sabate J, Fraser GE. Nutrient profiles of vegetarian and nonvegetarian dietary patterns. J Acad Nutrit Dietet. 2013;113(12):1610-9.

22. Carlsen E, Giwercman A, Keiding N, Skakkebæk NE. Evidence for decreasing quality of semen during past 50 years. BMJ. 1992;305(6854):609-13.

23. Van Waeleghem K, De Clercq N, Vermeulen L, Schoonjans F, Comhaire F. Deterioration of sperm quality in young healthy Belgian men. Hum Reprod. 1996;11(2):325-9.

24. Almagor M, Ivnitzki I, Yaffe H, Baras M. Changes in semen quality in Jerusalem between 1990 and 2000: a cross-sectional and longitudinal study. Arch Androl. 2003;49(2):139-44.

25. Haimov-Kochman R, Har-Nir R, Ein-Mor E, BenShoshan V, Greenfield C, Eldar I, et al. Is the quality of donated semen deteriorating? Findings from a 15 year longitudinal analysis of weekly sperm samples. Isr Med Assoc J. 2012;14(6):372-7.

26. Cardona Maya WD, Berdugo Gutierrez JA, de los Rios J, Cadavid Jaramillo AP. Functional evaluation of sperm in Colombian fertile men. Archivos espanoles de urologia. 2007;60(7):827-31.

27. Mayorga-Torres BJM, Camargo M, Cadavid AP, du Plessis SS, Cardona Maya WD. Are oxidative stress markers associated with unexplained male infertility? Androl. 2017;49(5):e12659.

28. Levine $\mathrm{H}$, Jorgensen $\mathrm{N}$, Martino-Andrade A, Mendiola J, Weksler-Derri D, Mindlis I, et al. Temporal trends in sperm count: a systematic review and meta-regression analysis. Hum Reprod Update. 2017;23(6):646-59.

29. Cordain L, Eaton SB, Sebastian A, Mann N, Lindeberg S, Watkins BA, et al. Origins and evolution of the Western diet: health implications for the 21st century. Am J Clin Nutr. 2005;81(2):341-54.

30. Ricci E, Al-Beitawi S, Cipriani S, Alteri A, Chiaffarino F, Candiani M, et al. Dietary habits and semen parameters: a systematic narrative review. Androl. 2018;6(1):104-16.

Cite this article as: Gómez Gutiérrez AM, Gómez Ramírez BD, Cardona Maya WD. Changes in the lifestyle and feeding habits that could improve the planet and human health: the reproductive case. Int $\mathbf{J}$ Reprod Contracept Obstet Gynecol 2020;9:458-60. 